\title{
Unstable Political Climate, Brain Drain and Development
}

\author{
Diana Loubaki \\ ESGAE (Ecole Supérieure de Gestion et d'Administration Economique). France
}

\begin{abstract}
The aim of this article is to study development when political climate is unstable like during forthcoming presidential elections in poor countries. The economic agents fear for their life and thus, on the one hand, the skilled labor increases his incentives to invest in human capital accumulation in order to leave abroad in a more developed country, the brain drain is stimulates. In contrast, the unskilled labor increases his savings in order to migrate to rural regions since violence occur in big cities, dualism emerges in the economy. Indeed, depending on the level of the unstable political climate parameter, the economy admits multiple equilibria where brain drain and dualism may vary and leads the economy inside a poverty trap or to development sustainability described by an inverted $U$-shape curve. Indeed, this article provides theoretical foundations explaining the impact of political climate on economic development in poorest developing countries.
\end{abstract}

Keywords: unstable political climate, dualism, development sustainability, brain drain, human capital accumulation

\section{INTRODUCTION}

Political uncertainty is often viewed as a major factor causing under development in poor countries. According to old development theories such as the Marxian thought, political uncertainty is caused by imperialism faced by poor countries in regard to industrial countries in order to maintain the government which retards development and growth in position to serve their own interest specifically in international exchange. In this article, political non stability is a necessary condition of growth and development. In contrast, human capital and dualism among rural and urban regions are engines of growth and development in poorest countries. This article focuses on political uncertainty climate which prevails when population is expecting to have election for the new president in least developed counties . That reality raises tensions in the country because most of the time, it is observed in poor countries that this situation leads to civil war raised by candidates for the president position and the winner is mostly the one who is the most stronger in weapons. Population often becomes kept in a vicious circle created by fighters for power or the greatest man choice process and obviously, population pay for military actions consequences .

This analysis uses the brain drain analysis to study development in that context. On the one hand, human capital component initiated by Becker and Schultz and introduced in growth analysis by Romer (1986) and Lucas (1988), plays a great role in the capability of a proportion of $p$ high skilled agents to move abroad in countries where the democracy establishment is effective in order to feel more in safety. On the other hand, a proportion of q low skilled agents leave urban to rural regions to protect them self from civil war and death occurrence since violence occurs in big cities creating Lewis (1954) dualism back in the economy. Those behaviors stimulate both the brain drain and dualism among rural and urban regions. Indeed, depending on the level of the unstable political climate parameter, $\lambda$ the economy admits multiple equilibria where high brain drain and high dualism i.e $p=q=1$ due to forthcoming violence and death occurrence kept the economy inside a poverty trap with low growth and 
development retard, when $0<\mathrm{p}, \mathrm{q}<1$ or low brain drain and low dualism prevail, the economy follows the development process with average growth rate, when $p, q=0$, brain drain and dualism are absent, the economy is becoming developed with a quite high growth rate and poverty absence, thus development is described by an inverted U-shape curve meaning that it is sustainable. Indeed, this article provides theoretical foundations which explain the impact of political climate on development in poor countries.

The scientific contribution of the model holds first on the introduction of unstable political climate effects on development inside both the brain drain and dualism concepts. Second, we established that, development follows an inverted U-shape curve inside the brain drain analysis, a finding due to Kuznets and means that, development is sustainable since required conditions are filled. Moreover, since internal emigration i.e urban to rural emigrations and the brain drain analysis effects on the development process depends on unstable political climate caused by democracy absence, it also guides agents' actions in the decision to migrate to feel in safety through human capital accumulation increase and international labor demand increase and/ or saving increase. In contrast, most of the brain drain models focus on human capital accumulation increase and use relative wages as the main criteria to the decision to emigrate, this model stipulates that political variables are neglected both by the politicians of development economics and by the world organizations in charge of developing countries management. Third, the model re introduces the debate on dualism of the economy between modern and traditional sectors as a key for development according to Lewis (1954). In contrast, as a proof of development retard, the reverse effect coupled to high brain drain i.e $\mathrm{p}=\mathrm{q}=1$, makes domestic human capital tends to 0 and drives the economic path toward a poverty trap in the spirit of the work of Azariadis-Drazen (1990). Instead of speaking about the return probability of the skilled labor mostly present in the brain drain models (DocquierRapoport, 2012), the model stipulates that, since political climate is stable, the skilled agent is inside the economic system to enhance production. Relative wages increase in this model highlight only normal brain drain i.e $0<\mathrm{p}<1$ and average internal migration i.e $0<\mathrm{q}<1$ but since the unstable political parameter signals appear greatly, high brain drain and dualism may occur i.e we may have $\mathrm{p}$ and q go to 1 . Indeed, depending on political climate of the country $\lambda$, development and growth may greatly fluctuate and be located far away from its steady state and lead to poverty and famine increase.

The model is a theory of economic development focused on two main literatures which are the brain drain and development pioneers thought. On the one hand, it can be distinguished three waves of the brain drain literature evolution. The first wave dates back to the late 1960s and includes mainly welfare analyses in standard trade-theoretic frameworks (e.g., Grubel and Scott, 1966, Johnson, 1967, Berry and Soligo (1969). These early contributions conclude to an essentially neutral impact of the brain drain on source countries and generally emphasize the benefits of free migration to the world economy. This is explained by the fact that highly skilled emigrants may leave behind part of their assets which complement remaining high and lowskill labor (Berry and Soligo, 1969), or simply by the role of remittances and other positive feedback effects that act to compensate sending countries for any real loss the brain drain may cause. From a broader perspective, these studies (especially Grubel and Scott, 1966) emphasize highly skilled emigrant contribution to knowledge. The second wave comes less than a decade later. Under the leadership of Jagdish Bhagwati, a series of alternative models were developed throughout the 1970s to explore the welfare consequences of the brain drain in various institutional settings. Domestic labor markets rigidities, informational imperfections, as well as fiscal and other types of externalities (Bhagwati and Hamada, 1974, McCulloch and Yellen, 1977) were introduced to emphasize instead the negative consequences 
of the brain drain for those left behind. Consequently, high-skill emigration was viewed as contributing to increased inequality at the international level, with rich countries becoming richer at the expenses of poor countries. The first papers to analyze the brain drain in an endogenous growth framework rested on similar arguments and also emphasized the negative effects of the brain drain (e.g., Miyagiwa, 1991, Haque and Kim, 1995). Finally, a third wave has emerged since the mid-1990s around the idea that migration prospects can foster domestic enrollment in education in developing countries, raising the possibility for a brain drain to be beneficial to the source country. The novelty of that recent literature is to show that under certain circumstances, the brain drain may ultimately prove beneficial (but of course is not necessarily so) to the source country, and do so while accounting for the various fiscal and technological externalities that were at the heart of the pessimistic models of the 1970s. On the other hand, development has always been conducted in several levels. The first level concerns policy recommendations and applications conducted both by world organizations and economic politicians in poor countries. The second level concerns theories in development which began in the years 40 with Roseinstein-Rodan, Lewis, Myrdal, Hirschman on the one hand and Prebisch, Singer on the other hand inspired by the Keynesian analysis which were rejected after the drop of the Berlin wall in 1989 making countries going back to liberalism in economics or to neoclassical growth models. But both the financial market crisis in developed world and the debt crisis in developing world have contrasted these believes. Economic development evolution remains now in models able to understand what is happening in the world and old theories have finally a sense after all and commonly used as tools to increase its comprehension (Krugman, 1994)

This model uses Lewis concept of unlimited supply of labor caused by the dualism existing between the traditional and the modern sectors of the economy that we assimilate to the one between rural and the urban regions. Internal migrations from urban to rural regions which is clearly detrimental for growth and development is used in order to model the fact that civil war occurrence in Africa take place in big cities and the analysis shows how poverty raises from those situations i.e disorders inside the country. This point is not really new, since we know that development policy began to be conducted with the Marshall plan and the creation of world organizations after the second war on the basis of the aid policy without significant result for most of the country in Sub-Saharan Africa until now. The results highlights by the analysis, is that, development needs political stability for sustainable growth to hold. Unfortunately, economic globalization claimed and the debt crisis generated by the policies conducted in poor countries until now, have both made economic development more difficult to understand and to ask in order to get answers about the mutations occurring in the world. Specifically with emerging countries introduction and the difficulties faced by the Sub-Saharan Africa's countries to get inside the virtuous cycle driven by external economies. Until now, we can't find appropriate model of development and the situation is worsened since the debt crisis have led to adjustment policy proposed by the World Bank and the IMF coupled with environmental issues like HIV/AIDS, those economies still far away from their development frontier, specifically in Sub-Saharan Africa. Recently, the Word Bank had worked greatly in poverty reduction as a development tool and has established a series of goals to achieve in 2015 called the millennium development goals. Development is measured by a human development index which includes per-capita income, education and life expectancy. This measure has enlarges the concept of development which must be sustainable. We find that development is an inverted U-shape, meaning that it is a sustainable vector which fills the characteristics of environment preservation.

The article is organized as follows, in section 2 we introduce the main assumptions and the setup of the model of unstable political climate in the poor country. In section 3 we 
characterize the competitive equilibrium. In section 4 , we introduce internal and external migration in the basic model presented earlier to study its impact on growth and development. In section 5 we conclude on the analysis conducted and open new horizons of research on the subject studied in the area of development economics.

\section{The simple Model of unstable political climate without Migrations}

Consider an overlapping-generation model with agents who live for two periods of time. The world is divided in two countries where the one is developed and still exogenous in the whole model and the other is not developed yet. Developing country's variables are indexed by . At each period of time, the production sector is composed of high and low tech sectors, two production sectors manufacture one homogenous consumption good which differ both in their technological sophistication and their skill intensity. The education sector offers the young agents the opportunity to accumulate human capital. In each period, a new generation of agents enters in the economy with a zero endowment of human capital. Young agents must decide whether to accumulate human capital and get inside the education sector as students in order to become a skilled labor next period or to work in production sector as unskilled labor, . The bond market is regulated by an endogenous interest rate, . The High-Tech sector utilizes the cutting edge non rival technological vintage, , the skilled labor to adapt new technology into the production process and the unskilled labor stock, to perform routine tasks. The low tech sector utilizes old technology, , the unskilled labor to perform routine tasks into the production. Following Eicher (1996), the growth rate of the economy is defined such that $g=\frac{A_{t+1}-A_{t}}{A_{t}}=\mu S_{t}^{\bar{d}}$ where $\mu$ is technological change growth rate.

\section{The Production Sector}

The high tech production function is thus expressed by (1) i.e

$$
H_{t}=A_{t} F\left(U_{t}^{H}, E_{t}^{\bar{d}}\right)
$$

Where $\mathrm{F}$ is a linear homogenous monotonic production function. Following Nelson and Phelps (1966), the absorption of new technology in the High-Tech sector is skill intensive. However, once a technology has been absorbed, production requires unskilled labor only. Therefore, the low tech production sector uses only old technology, (absorbed in the previous period) and unskilled labor to perform simple tasks.

The low tech production function is then expressed by Equation (2) i.e $L_{t}=\delta A_{t-1} U_{t}^{L}$

Where $\delta>0$ is the unskilled labor productivity parameter. When a new technology is introduced in the High-Tech sector, the recently absorbed technology can now be used in the Low-Tech sector which renders the oldest production method no longer profitable and thus discarded.

Production of the consumption goods takes place in a perfect competitive sector. Rewriting $\mathrm{H}$

in intensive form leads to

$$
F\left(U_{t}^{U}, E_{t}^{\bar{d}}\right)=f\left(\frac{U_{t}^{H}}{E_{t}^{\bar{d}}}\right) E_{t}^{\bar{d}}
$$

then profit maximization yields the standard

first order conditions:

$$
w_{t}^{E}=A_{t}\left[f\left(\frac{U_{t}^{H}}{E_{t}^{\bar{d}}}\right)-f^{\prime}\left(\frac{U_{t}^{H}}{E_{t}^{\bar{d}}}\right) \frac{U_{t}^{H}}{E_{t}^{\bar{d}}}\right]
$$




$$
\begin{aligned}
& w_{t}^{U H}=A_{t} f^{\prime}\left(\frac{U_{t}^{H}}{E_{t}^{\bar{d}}}\right) \\
& w_{t}^{U L}=\delta A_{t-1}
\end{aligned}
$$

The factor market equilibrium requires

$$
w_{t}^{U L}=w_{t}^{U H}=w^{U}
$$

\section{The Relative Wage Rates}

Equation (6) means that, the marginal productivities of the unskilled labors of the both sectors of production must be the same. Given the linearity of $F($,$) , the relative wage in the High Tech$ sector depends only on the relative factor prices i.e

$$
\frac{w_{t}^{E}}{w_{t}^{U H}}=\varsigma\left(\frac{U_{t}^{H}}{E_{t}^{\bar{d}}}\right)
$$

The derivative function of is positive i.e. . Substituting (3) and (4) into the factor market equilibrium condition (6) yields an expression of the relative factor demand in the High-Tech sector i.e. $\frac{U_{t}^{H}}{E_{t}^{\bar{d}}}=\varepsilon\left(\frac{A_{t}}{A_{t-1}}\right)$ where $\varepsilon(,) \cong f^{\prime-1}$ which implies $\varepsilon(,) \succ 0$ and $\varepsilon^{\prime}(,) \succ 0$

After substituting the rate of technological change given in function of the student stock in the relative wage of the skilled labor i.e equation (7), it can now be expressed such as a function of past investment in human capital stock i.e.,

$$
\frac{w_{t}^{E}}{w_{t}^{U H}}=g\left(\frac{\delta}{1+\mu S_{t-1}^{\bar{d}}}\right)
$$

The derivative of the previous function is negative i.e., $g^{\prime}()<0,, g($, $)$ is also the composite of $\varepsilon$ $($,$) and s($,).

Equation (8) highlights the forceful implication of the differing factor intensity and technological sophistication in the two production sectors. Human capital investment increase induces the skilled labor wage rate increase. Indeed, human capital investment increase in $t-1$ must also increase technological change and thereby good quality as well. All that increases the economic growth rate and accelerate the development process. Those changes create a bias in the skilled labor demand and induce relative wages increase. Therefore the production function structure establishes a relationship between human capital investment at time $t$ and relative wages at time $t+1$ i.e., there exist a relationship between technological change at time $t$ and the skilled labor stock demand at time $t+1$.

In the rest of the article, for simplicity we assume $g(x)=1 / x$ which implies $g^{\prime}(x)=-(1 / x 2)<0$ and the relative wages can now be expressed by (9) i.e.,

$$
\frac{w_{t}^{E}}{w_{t}^{U H}}=\frac{1+\mu S_{t-1}^{\bar{d}}}{\delta}
$$

The above result means that high human capital investment at time $t-1$ increases also the skilled labor stock. Then technological change speeds since the relative wage increase and thereby increases the higher skilled labor stock in the developing country's economy. If the higher skilled labor stock is high enough, knowledge externalities spread all over the low 
skilled labor stock through the use of the older technology. Equation (9) highlights the forceful implication of the differing factor intensity and technological sophistication in the two production sectors. Human capital investment increase induces the skilled labor wage rate increase. Indeed, human capital investment increase in $t-1$ must also increase the higher skilled labor stock. Technological change increases and thereby good quality as well. All that increases the economic growth rate and accelerate the development process. Those changes create a bias in the skilled labor demand and induce relative wages increase. Therefore the production function structure establishes a relationship between human capital investment at time $t$ and relative wages at time $t+1$ i.e., there exist a relationship between technological change at time $t$ and the skilled labor stock demand at time $t+1$.

\section{Utility Optimization}

Individuals share the same utility function and they are hurt by unstable political climate which may prevail in the country. Therefore, the utility function of the agents born at $t$ is given by (10) i.e.,

$$
W^{j}=\ln \left(c_{t}^{j}\right)+\beta \ln \left(c_{t+1}^{j}\right)-\lambda \ln \left(d_{t+i}^{j}\right)
$$

Where $\lambda \geq 0$ is the parameter which measures the impact of unstable political climate on the well being variable of the agents where $d_{t+i}^{j}$ is unstable political climate variable i.e the way democracy absence acts on the agents utility function with $i=0,1$ respectively for the unskilled and the skilled labor. The parameter $\beta>0$ is the second period consumption elasticity, $j=U,(S, E)$ represents the respective career paths of the unskilled and the skilled labors, $c_{t}^{j}$ and $c_{t+1}^{j}$ represent per-capita consumptions in $t$ and in $t+1$ respectively. Each unskilled labor receives a wage rate income $w_{t}^{U}$ during his first period of life and saves the remainder $x_{t}$ for his resting period and $d_{t+i}^{j}$ to prevent the military action of the unstable government since the presidential elections is expect to come, so he can hide himself somewhere in the country where there is more safety. Each student borrows $b_{t}$ in the bond market to finance first, his incentives to invest in human capital against a future wage rate income $w_{t+1}^{E}$ he pays the tuition, $z_{t}$, second, his incentives to migrate abroad after being skilled, third, his consumption, $c_{t}^{S}$. The budget constraints of the student are given by (13)-(14) whereas (11)-(12) are the unskilled labor budget constraint i.e

$$
\begin{aligned}
& c_{t}^{U}=w_{t}^{U}-x_{t}-d_{t}^{U} \\
& c_{t+1}^{U}=\left(1+r_{t}\right) x_{t}
\end{aligned}
$$

and

$$
\begin{aligned}
& c_{t}^{S}=b_{t}-z_{t} \\
& c_{t+1}^{E}+d_{t+1}^{E}=w_{t+1}^{E}-\left(1+r_{t}\right) b_{t}
\end{aligned}
$$

The first order conditions from the maximization problems of the unskilled labor provide percapita feelings which provide from political tensions in the country and savings expressed by equations (15) and (16) i.e

$$
\begin{aligned}
& d_{t}^{U}=\left(\frac{-\lambda}{1+\beta-\lambda}\right) w_{t}^{U} \\
& x_{t}=\left(\frac{\beta}{1+\beta-\lambda}\right) w_{t}^{U}
\end{aligned}
$$


An increase in the parameter $\lambda$ increases unskilled labor tension on negative feelings about political evolution which may drive to civil war. Thus he ought to leave for somewhere else inside the country like going to his native village and leave urban life. Indeed, as we can see through equation (16), his savings increases like to transfer funds for later period because of this uncertain life. Since $c_{t}^{U}-d_{t}^{U}=c_{t+1}^{U} / 1+r_{t}$ is the equilibrium, it yields three cases which are: $|\lambda| \succ|\beta-1|$ the agent is expecting to face high damages in his daily life, when $|\lambda|<|\beta-1|$ the agent doesn't fear a lot for his life, things seem quite going good. Finally when $|\lambda|=|\beta-1|$ feelings are stable in regard to political impact in daily life.

The first order conditions from the respective maximization problems of the skilled labor provide per-capita well being variable and borrowing (17) and (18)

$$
\begin{aligned}
& \frac{d_{t+1}^{E}}{1+r_{t}}=\left(\frac{-\lambda}{1+\beta-\lambda}\right)\left[-z_{t}+\frac{w_{t+1}^{E}}{\beta\left(1+r_{t}\right)}\right] \\
& b_{t}=\left(\frac{1}{1+\beta-\lambda}\right)\left[(\beta+\lambda) z_{t}+\frac{w_{t+1}^{E}}{\beta\left(1+r_{t}\right)}\right]
\end{aligned}
$$

Computing $\frac{\partial}{\partial \lambda}\left(\frac{-\lambda}{1+\beta-\lambda}\right)$ a variable of equation (17) in regard to $\lambda$ in order to study its sign, yields to non existence of a real solution because $\beta^{2}-2 \beta<0$, since $\beta$ is a parameter, therefore political variable movement is complex and hard to determinate easily its law of motion without serious discussions with international other organizations which work with the poor country government (this result is validated for the unskilled agent too). Otherwise, since the skilled labor doesn't receive income during his training period until he begins to work, the equilibrium per-capita borrowing increases in their future discounted income, $\frac{w_{t+1}^{E}}{\beta\left(1+r_{t}\right)}$ An increase in the parameter $\lambda$ increases student's demand for funds since more money is deferred into the future in order to migrate abroad because of political tensions in the country. Higher direct education cost reduces the current period consumption and allow students transfer more income from the future to the present through the increase of their borrowing . Since $c_{t}^{S}=\left(d_{t+1}^{E}+c_{t+1}^{E}\right) / 1+r_{t}$ expresses the equilibrium in well being of the agent, it yields in parameters term, if $\lambda=1$ which means that the situation is bad and the utility function will be highly damaged if actions for migration are not take, if $\lambda=0$, then there is an equilibrium in development economics. Finally we may have $0<\lambda<1$ which means that unstable political climate may be low or high, democracy respect is in process, then the brain drain may be low or high.

To express human capital competitive equilibrium, we follow Eicher(1996) and assume that, since the young agents enter in the economy as identical agents they must be indifferent between either career path i.e $W^{U}=W^{S}$. The above assumption leads to the expression (solving

$$
\begin{gathered}
\left.c_{t}^{U}=c_{t}^{S}\right) \\
\frac{w_{t+1}^{E}}{R_{t}}=z_{t}+w_{t}^{U}
\end{gathered}
$$




\section{The Bond Market Equilibrium}

The bond market clearing condition expressed by Equation (20) defines the equilibrium interest rate i.e

$$
b_{t} S_{t}^{\bar{d}}=x_{t} U_{t}^{\bar{d}}
$$

We assume that $S_{t}^{\bar{d}}+U_{t}^{\bar{d}}=1$. Per-capita supply and demand of capital in conjunction with the lenders and borrowers determine the equilibrium endogenous interest rate. Substituting percapita saving rate (16) and per-capita borrowing (18) in the bond market equilibrium condition using the career path equation, yields the bond market clearing interest rate (21) i.e.,

$$
R_{t}=\frac{w_{t+1}^{E}}{\beta\left[\frac{U_{t}^{\bar{d}}}{S_{t}^{\bar{d}}} w_{t}^{U}-z_{t}\right]}
$$

Where $R_{t}=1+r_{t}$

\section{THE EQUILIBRIUM}

Introducing Equation (19) into Equation (22) characterizes the equilibrium such as a couple of functions of past and current human capital stocks of students expressed by(22) i.e

$$
S_{t}^{\bar{d}}=\frac{\beta / 1+\beta}{1+\left[\left(\frac{1+\beta+\lambda}{1+\beta}\right)\left(\frac{1+\mu S_{t-1}^{\bar{d}}}{\delta}\right)\right]}
$$

The demand of human capital investment is decreasing with past human capital accumulation and this relationship summarizes two feedback effects along the transitory dynamics. They are first, both the increase of skilled labor while political climate captured by the parameter $\lambda$ is high, actual human capital decreases because they leave and go abroad, development is retarded. Otherwise if $\lambda$ is low, current human capital demand tends to increase because incentives to migrate are low. Finally, when $\lambda$ is stable, the relationship between current and past human capital is decreasing in average term because of the cost of education. This result is similar to those found by Eicher (1996) for private education which is costly and thus decreasing function of past and current stock. This model analyzes the same kind of argument inside which is included political variables.

Curve 1 displays the relationship between current and past human capital, but the curve also depends on the margin propensity to save, $\theta=\beta / 1+\beta$ and political non stability parameter, $\lambda$. The curve goes up when the margin propensity to save, $\theta$ goes towards 1 and $\lambda$ goes to 0 which is its upper level.

When the margin propensity to save, $\theta$ is low i.e close to 0 and $\lambda$ close to 1 , the curve is at its lower position. Finally when both the margin propensity to save and $\lambda$ are inside 0 and 1 , the curve is stable at its intermediate level.

In contrast, Curve 2 displays the relationship between current and past unskilled labor stock, like in the previous case, the curve depends on the same two parameters which are political non stability parameter $\lambda$ and the margin propensity to save, $\theta$. The curve goes up when $\theta$ goes to 1 and $\lambda$ goes to 0 which is its upper level. When $\theta$ is low i.e close to 0 and $\lambda$ close to 1 , the curve is at its lower position. Finally when both $\theta$ and $\lambda$ are inside 0 and 1 , the curve is stable at its intermediate level.

\section{Curve 1}




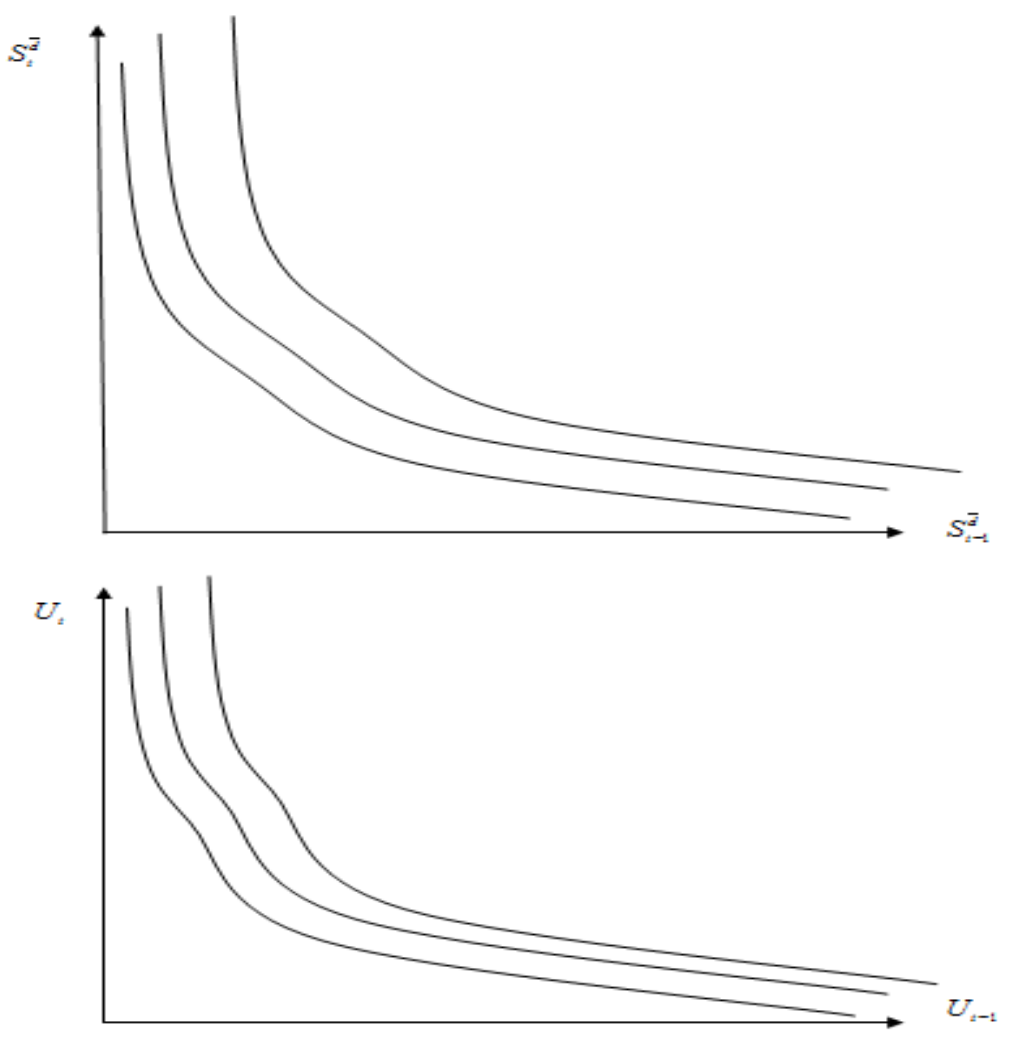

Definition1: the balanced growth is the locus in the space where $S_{t}^{\bar{d}}=S_{t-1}^{\bar{d}}=S^{\bar{d}}$

Proposition 1: along the balanced growth path, the long run growth is a unique solution defined such that:

$$
g=\frac{\mu \beta / 1+\beta}{1+\frac{1}{\delta}\left(\frac{1+\beta+\lambda}{1+\beta}\right)}
$$

See the appendix for proof

Proposition2: according to the growth rate given by equation (23), the mechanics of economic development are given by the propensity to save, , technological growth rate, and the unskilled labor productivity parameter, in contrast, unstable political climate parameter is a mechanics of development stagnation.

The results provided by this first analysis join the results given by neoclassical growth models like Solow (1956), Romer (1990) and Lucas (1988) where technological change, human capital and savings play a great role in economic development.

\section{The Model of unstable political climate with internal migration and international} migration (the brain drain)

Following Docquier and Rapoport (2012), we assume that, an exogenous fraction p of the highly skilled population leaves the country. For simplicity, we consider that low-skill workers do not migrate abroad only in country sides of the poor country to protect against tensions and violence due to potential civil war which mostly occur in big cities in the country. The proportion of highly skilled among remaining adults becomes:

$$
\pi_{t}=\frac{(1-p) S_{t}^{\bar{d}}}{1-p S_{t}^{\bar{d}}}
$$


With $\frac{\partial \pi_{t}}{\partial S_{t}^{\bar{d}}}=\frac{1-p}{\left(1-p S_{t}^{\bar{d}}\right)^{2}} \succ 0$ and $\frac{\partial \pi_{t}}{\partial p}=-\frac{S_{t}^{\bar{d}}\left(1-S_{t}^{\bar{d}}\right)}{\left(1-p S_{t}^{\bar{d}}\right)^{2}}<0$ which means that since unstable political climate is an increasing function of incentives to accumulate human capital it also leads to the brain drain increase. The increase of $\mathrm{p}$ increases the brain drain, skilled labor leave the country, innovations or high technology assimilation capability, $\mu$ decreases and development is retarded.

For unskilled labor, civil war forthcoming makes a proportion of agent q leave the city for countryside and the remaining proportion is thus:

$$
\pi_{t}^{U}=\frac{(1-q) U_{t}^{\bar{d}}}{1-q U_{t}^{\bar{d}}}
$$

With $\frac{\partial \pi_{t}^{U}}{\partial U_{t}^{\bar{d}}}=\frac{1-q}{\left(1-q U_{t}^{\bar{d}}\right)^{2}} \succ 0$ and $\frac{\partial \pi_{t}^{U}}{\partial q}=-\frac{U_{t}^{\bar{d}}\left(1-U_{t}^{\bar{d}}\right)}{\left(1-q U_{t}^{\bar{d}}\right)^{2}}<0$ which means that since the proportion of population who leave the city is high, little economy productivity, $\delta$ is getting broken and thus economy cease because as empirically observed most of the time they face burglars too who take revenge of the situation to frighten the population who leave all for nowhere looking for a peaceful place.

Consequently, if $p=q=0$ then political climate is stable and first, the brain drain almost not exist i.e $\pi_{t}=S_{t}^{\bar{d}}$, second, there is no dualism between the urban and the rural regions of the country i.e $\pi_{t}^{U}=U_{t}^{\bar{d}}$. If $0<q, p<1$ then the brain drain and domestic migrations are normal because tensions on civil war event are not effective, we have equations (24) and (25) in action. But when $\mathrm{p}$ and $\mathrm{q}$ tends toward 1 , then tensions on civil war occurrence in the country are seriously considered then we may have $\pi_{t}=0$ and $\pi_{t}^{U}=0$. 


\section{Curve 2}

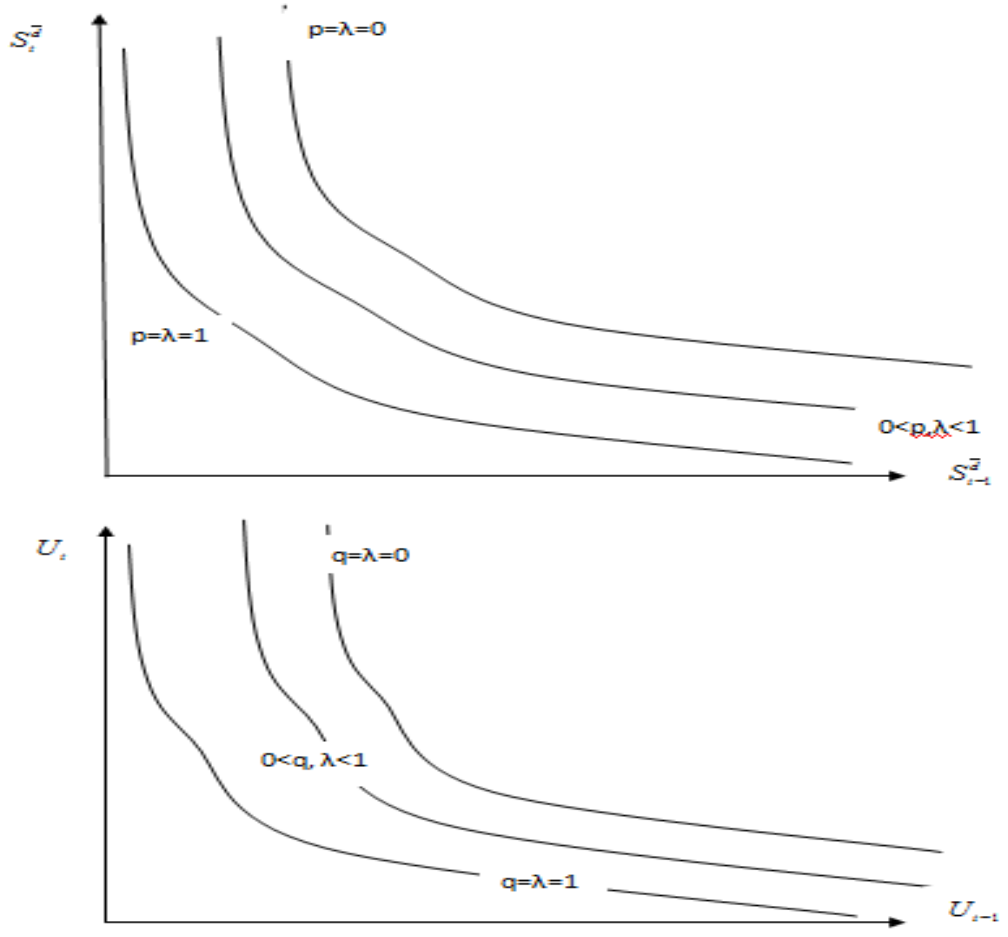

Curve 3

Curve4

Curve 1 displays the relationship between current and past human capital, but the curve also depends on both the brain drain, $p$ and political non stability parameter, $\lambda$. The curve goes up when $p$ goes to 0 and $\lambda$ goes to 0 which is its upper level. When both $p=1$ and $\lambda=1$, the curve is at its lower position. Finally when both $\mathrm{p}$ and $\lambda$ are inside 0 and 1 , the curve is stable at its intermediate level. In contrast, Curve 2 displays the relationship between current and past unskilled labor stock, like in the previous case, the curve depends on two parameters which are political non stability parameter $\lambda$ and internal migration from urban to rural regions, $\mathrm{q}$. The curve goes up when q goes to 0 and $\lambda$ goes to 0 which is its upper level. When both $q=1$ and $\lambda=1$, the curve is at its lower position. Finally when both $\mathrm{p}$ and $\lambda$ are inside 0 and 1 , the curve is stable at its intermediate level.

\section{Presentation of the results and Discussions}

In the following arrays, $\lambda$ causes $\mathrm{p}, \mathrm{q}$ which thereby, characterizes growth and development regimes. Recalling that, $\lambda=1$ means civil war is occurring or will occur, $0<\lambda<1$ means there exist possibilities for civil war to occur or not to occur, $\lambda=0$ means peace will remains along the political event.

BD: brain drain; D: dualism, UPC: unstable political climate

Table 1: qualification of the poor country political environment

\begin{tabular}{|c|c|c|c|}
\hline $\begin{array}{c}\text { Characteristics of the } \\
\text { Economyt }\end{array}$ & $\begin{array}{c}\lambda=0 \\
\text { Political stability }\end{array}$ & $\begin{array}{c}0<\lambda<1 \\
\text { Political average stability }\end{array}$ & $\begin{array}{c}\lambda=1 \\
\text { Civil war }\end{array}$ \\
\hline $\mathrm{p}=\mathrm{q}=0$ & $\begin{array}{l}\mathrm{BD}=0 ; \quad \mathrm{D}=0 ; \quad \mathrm{UPC} \quad \text { is } \\
\text { absent }\end{array}$ & $\begin{array}{l}\mathrm{BD}=0 ; \quad \mathrm{D}=0 ; \quad \mathrm{UPC} \text { is } \\
\text { average }\end{array}$ & $\begin{array}{l}\mathrm{BD}=0 ; \mathrm{D}=0 ; \text { and } \mathrm{UPC} \text { is } \\
\text { high }\end{array}$ \\
\hline $0<\mathrm{p}, \mathrm{q}<1$ & $\begin{array}{l}\text { Average BD; average D; } \\
\text { UPC is absent }\end{array}$ & $\begin{array}{l}\mathrm{BD}=0 ; \quad \mathrm{D}=0 ; \quad \mathrm{UPC}=\text { is } \\
\text { Average }\end{array}$ & $\mathrm{BD}=0 ; \mathrm{D}=0 ; \mathrm{UPC}$ is high \\
\hline $\mathrm{p}=\mathrm{q}=1$ & $\begin{array}{l}\text {,High } \mathrm{BD} \text {, high } \mathrm{D} \text {; UPC } \\
\text { is absent }\end{array}$ & $\begin{array}{l}\text { High BD; high D; UPC is } \\
\text { averagely stable }\end{array}$ & $\begin{array}{l}\text { High BD; high D; UPC is } \\
\text { High }\end{array}$ \\
\hline
\end{tabular}


Indeed, if $\lambda=0$ and $p, q>0$ then the model joins the results of standard brain drain and dualism models where they are considered to be detrimental for growth and development. Moreover, if $\lambda=0$ and $p=q=1$, then the both migrations are caused by poverty and other economic gains. Cities are not engine of growth, unemployment is high and food is lacking, thus campaigns are better. Otherwise, if $0<\lambda<1$ and $p=q=0$ then the model is out of the standard brain drain and dualism models in such a way that, if $\lambda$ is high, then traditional brain drain reverse dualism is absent because civil war occurrence has closed frontiers both in international and in domestic plans. Or if $\lambda$ is low, then it can also be seen that, civil war risks are not high enough for population to move far away from the place they usually leave. Finally, if $\lambda=1$ and $p=q=0$, the interpretation is the same as the case viewed before. $\lambda=1$ and $p=q=1$, then political climate non stability is seriously taken and has negative effects on growth and development. Production cease and famine may occur as long as population keeps living with provision kept for a danger only, if longer it will be unsustainable for them to keep being alive.

We can translate the previous array in terms of growth and development in table 2

Table 2: the impact of political uncertainty on growth and development

\begin{tabular}{|c|c|c|c|}
\hline $\begin{array}{c}\text { Impact of } \lambda \text { on growth } \\
\text { and development }\end{array}$ & $\begin{array}{c}\lambda=0 \\
\text { Political stability }\end{array}$ & $\begin{array}{c}0<\lambda<1 \\
\text { Political average stability }\end{array}$ & $\begin{array}{c}\lambda=1 \\
\text { Civil war }\end{array}$ \\
\hline $\mathrm{p}=\mathrm{q}=0$ & $\begin{array}{c}\text { High Economic } \\
\text { Development possibility. } \\
\text { It looks like planed } \\
\text { Communism countries } \\
\text { where emigrations were } \\
\text { zero }\end{array}$ & $\begin{array}{l}\text { Development is holding } \\
\text { little and little }\end{array}$ & $\begin{array}{c}\text { Population is kept } \\
\text { prisoner in the country } \\
\text { and production cease due } \\
\text { to high civil war degree } \\
\text { Growth and Development } \\
\text { can't occur }\end{array}$ \\
\hline $0<\mathrm{p}, \mathrm{q}<1$ & $\begin{array}{l}\text { Possible Development } \\
\text { through innovations } \\
\text { increase and transfers of } \\
\text { workers from traditional } \\
\text { to modern economy }\end{array}$ & $\begin{array}{l}\text { Skilled labor proportion } \\
\text { is not high enough for } \\
\text { Development to emerge } \\
\text { faster }\end{array}$ & $\begin{array}{l}\text { The economy is kept in a } \\
\text { poverty trap because of } \\
\text { average civil war degree. } \\
\text { Growth and Development } \\
\text { are retarded }\end{array}$ \\
\hline $\mathrm{p}=\mathrm{q}=1$ & $\begin{array}{l}\text { The modern sector needs } \\
\text { to absorb the least skilled } \\
\text { workers in the production } \\
\text { sector, there is a dualism } \\
\text { in the sens of Lewis in } \\
\text { the economy. Under } \\
\text { Development with high } \\
\text { Migrations }\end{array}$ & $\begin{array}{l}\text { Development needs brain } \\
\text { drain and dualism cease } \\
\text { for the process to } \\
\text { accelerate since low } \\
\text { skilled labor is } \\
\text { transferred in the modern } \\
\text { sector since } \lambda \text { is low, } \\
\text { otherwise if } \lambda \text { is high, the } \\
\text { country is left by its } \\
\text { population }\end{array}$ & $\begin{array}{l}\text { The economy is kept in a } \\
\text { poverty trap without } \\
\text { specialization, it is the } \\
\text { full under development } \\
\text { holding during low civil } \\
\text { war degree since people } \\
\text { can move. Growth and } \\
\text { Development occurrence } \\
\text { is slows }\end{array}$ \\
\hline
\end{tabular}

Indeed, if $\lambda=0$ and $\mathrm{p}, \mathrm{q}>0$ and quite low, development can occur, otherwise if $\mathrm{p}$ is too high, human capital accumulation is not enough to faster development in conformity to the endogenous growth with human capital literature. The same thing can be observed if $\mathrm{q}$ is too high which means that urban regions are not developed enough to provide food and jobs to the population. The country is mostly rural and agriculture of subsistence prevails. If $0<\lambda<1$ and $p$, $\mathrm{q}>0$ then 2 scenarios can occur, if $\lambda$ is low as well as $\mathrm{p}, \mathrm{q}$, then development can follow its trajectory and approaches its frontier, otherwise if $\lambda$ is high and $\mathrm{p}, \mathrm{q}$ are too high, human capital accumulation is not enough and regions are too much heterogenous and can't faster development in conformity to growth and development literatures. If $\lambda=1$ and if $p$, $q$ low, then development is not altered by political problems because people are not afraid enough to move, or it is but moving is no more possible. If $\mathrm{p}$, $\mathrm{q}$ are high, then civil war is great, people can move or leave the country, development can't follow its trajectory and enlarges the gap to its frontier. 
Table 3: Others scenarios possibilities

\begin{tabular}{|c|l|l|l|}
\hline $\begin{array}{c}\text { Characteristics of growth } \\
\text { and development }\end{array}$ & \multicolumn{1}{|c|}{$\begin{array}{c}\lambda=0 \\
\text { Political stability }\end{array}$} & $\begin{array}{l}0<\lambda<1 \\
\text { Political average stability }\end{array}$ & \begin{tabular}{c}
\multicolumn{1}{c|}{$\lambda=1$} \\
Political non stability
\end{tabular} \\
\hline $0<\mathrm{p}<1, \mathrm{q}=0$ & $\begin{array}{l}\text { Average BD; D absence } \\
\text { and PUC absent }\end{array}$ & $\begin{array}{l}\text { Average BD; D absence; } \\
\text { PUC is average }\end{array}$ & $\begin{array}{l}\text { Average BD; D absence } \\
\text { and PUC is high }\end{array}$ \\
\hline $0<\mathrm{p}<1, \mathrm{q}=1$ & $\begin{array}{l}\text { Average BD; high D and } \\
\mathrm{PUC} \text { absent }\end{array}$ & $\begin{array}{l}\text { Average BD; high D; } \\
\text { PUC is average }\end{array}$ & $\begin{array}{l}\text { Average BD; high D and } \\
\text { PUC is high }\end{array}$ \\
\hline $\mathrm{p}=0,0<\mathrm{q}<1$ & $\begin{array}{l}\mathrm{BD}=0 ; \mathrm{D} \text { is average and } \\
\mathrm{PUC} \text { is absent }\end{array}$ & $\begin{array}{l}\mathrm{BD}=0 ; \mathrm{D} \text { is average and } \\
\mathrm{PUC} \text { is verage }\end{array}$ & $\begin{array}{l}\mathrm{BD}=0 ; \mathrm{D} \text { is average and } \\
\mathrm{PUC} \text { is high }\end{array}$ \\
\hline $\mathrm{p}=1,0<\mathrm{q}<1$ & $\begin{array}{l}\mathrm{BD} \text { is high; } \mathrm{D} \text { is average } \\
\text { and } \mathrm{PUC} \text { is absent }\end{array}$ & $\begin{array}{l}\text { BD is high; D is average } \\
\text { and PUC is average }\end{array}$ & $\begin{array}{l}\text { BD is high; D is average } \\
\text { and PUC is high }\end{array}$ \\
\hline
\end{tabular}

Table 4: second degree effect of $\lambda$ on growth and development

\begin{tabular}{|c|c|c|c|}
\hline $\begin{array}{c}\text { Effect of } \lambda \text { on growth and } \\
\text { development }\end{array}$ & $\begin{array}{c}\lambda=0 \\
\text { Political stability }\end{array}$ & $\begin{array}{c}0<\lambda<1 \\
\text { Political average stability }\end{array}$ & $\begin{array}{c}\lambda=1 \\
\text { Political non stability }\end{array}$ \\
\hline $0<\mathrm{p}<1, \mathrm{q}=0$ & $\begin{array}{c}\text { Development without } \\
\text { dualism }\end{array}$ & $\begin{array}{c}\text { Development possibly } \\
\text { occurs without dualism }\end{array}$ & $\begin{array}{c}\text { Civil war occurs in } \\
\text { average level, the } \\
\text { economy is slowed }\end{array}$ \\
\hline $0<\mathrm{p}<1, \mathrm{q}=1$ & $\begin{array}{c}\text { Development with } \\
\text { dualism }\end{array}$ & $\begin{array}{c}\text { Development possibly } \\
\text { occurs with dualism }\end{array}$ & $\begin{array}{c}\text { Civil war occurs in } \\
\text { average level, the } \\
\text { economy is slowed }\end{array}$ \\
\hline $\mathrm{p}=0,0<\mathrm{q}<1$ & $\begin{array}{c}\text { Development focused on } \\
\text { the modern sector }\end{array}$ & $\begin{array}{c}\text { Development possibly } \\
\text { occurs through the } \\
\text { modern sector }\end{array}$ & $\begin{array}{c}\text { Strong Civil war occurs, } \\
\text { the economy is kept in } \\
\text { the trap }\end{array}$ \\
\hline $\mathrm{p}=1,0<\mathrm{q}<1$ & $\begin{array}{c}\text { Traditional economics } \\
\text { without human capital }\end{array}$ & $\begin{array}{c}\text { Traditional economics } \\
\text { without human capital }\end{array}$ & $\begin{array}{c}\text { Civil war occurs, the } \\
\text { economy is kept in the } \\
\text { trap of zero human } \\
\text { capital }\end{array}$ \\
\hline
\end{tabular}

$\lambda=0$ and $p=0, q=1$ replicates the situation presented by Lewis (1954) for whom development can provide from the cease of dualism among the modern and the traditional sector. Instead, here $\mathrm{q}=1$ means that population is going back to countryside to hide himself from danger for their life, thus it is the opposite of Lewis view of development. Whereas, $p=1$ means human capital accumulation absence, replicates Azariadis-Drazen (1990) findings i.e this situation leads the economy inside a trap of poverty. When $(p=q=0)$, describe the big country where migrations are low, democracy is established and agents are willing to work more for development process continuity. Moreover, if one assumes that emigration does not modify the incentive to invest in education (i.e.,human capital accumulation stock given in (22) is unchanged), the brain drain impact on the proportion of highly skilled among remaining adults is clearly negative (the brain drain is less harmful if few people are educated or if nearly all adults are educated). This would translate in Figure 3 by a shift of the $S_{t}^{\bar{d}}=f\left(S_{t-1}^{\bar{d}}\right)$ curve to the lower level: for a given technological change growth rate, $\mu$ the economy-wide average level of human capital decreases and $\delta$ increases. In turn, this reduces the capacity to adopt in relatively poor countries and the capacity to innovate in relatively advanced migrant sending countries. Stable equilibria given by $\pi_{t}=S_{t}^{\bar{d}}=f\left(S_{t-1}^{\bar{d}}\right)$ and $\pi_{t}^{U}=U_{t}^{\bar{d}}=h\left(U_{t-1}^{\bar{d}}\right)$ go down: the economy ends up having less human capital and being more distant to the frontier. Those arguments are based on the existence of technological externalities related to human capital accumulation and strengthened by additional mechanisms like unstable political climate in the poor country. First, if political disturbances are high enough to greatly rise the brain drain, it may be sufficiently important to positively affect productivity in the host economy (i.e., increases), this will further increase the technological gap with the leader country. In the same way, if political disturbances are high enough to greatly affect unskilled part of the population, domestic migrations from urban to rural parts of the country increase in order to leave big 
cities and protect them self against potential civil war occurring, development is retarded because dualism between traditional and modern sectors (Lewis, 1954 ) is getting stronger, meaning that unemployment is rising and the labor market no more exist. Self reinforcement of the economy not exists. Economic dualism is the one in which traditional production paid lower wages and/or participated in the market less than the modern sector, thus carry unlimited supply of labor. This also means that, modern methods of production are potentially more productive than traditional ones, indeed leads faster to development, but their productivity edge is large enough to compensate for the necessity of paying higher wages only if the market is large enough. But the size of the market depends on the extent to which modern techniques are adopted, because workers in the modern sector earn higher wages and/or participate in the market economy more than traditional workers. So if modernization can be gotten started on a sufficiently large scale, it will be self-sustaining, but it is not the case, therefore, the economy is getting kept in a trap in which the process never gets going. Consequently, production decrease, national income does the same thing, thus per-capita income too and poverty keeps increasing, finally the economy still under developed. In parallel, the concentration of human capital in the most advanced economies which may stimulate technological progress at the world leave through contact with external economies can't appear in the little country because of linkages absence (Hirschman, 1958) at the moment due to civil war. Grubel and Scott (1966), Kuhn and Mc Ausland $(2009,2010)$ and Mountford and Rapoport (2010) stressed that the main contribution of the brain drain to the world economy and, in turn, to the origin countries, was to accelerate the rate of technology growth. But those authors assume stability in the country, so that, the brain drain can do so. Second, if the impact of unstable political climate is low, domestic migration emerges in the positive way i.e rural to urban, thus modern sector absorb most of unlimited supply of labor available of traditional sector and the economy increases, $\delta$ first because a number of little activities of the economy reinforce the positive effects on development through the ruled of the labor markets and create externalities with the high skilled labor and the brain drain $\mathrm{p}$ is at least such that $0<\mathrm{p}<1$. In Bhagwati and Hamada (1974), international integration of labor markets for highly skilled workers induces a loss for poor countries (this model assumes so only since $\lambda$ approaches 1 ) because, a higher integration of high-skill labor markets makes international highly skilled wages more observable and leads the educated elite to bargain for higher wages. Most of the brain drain models assume that the wages are the cause of international migration of the skilled labor, this model accept this argument since $0<\mathrm{p}<1$, but when $\lambda$ increase a lot, $p$ does the same thing and introduces an additional argument to emigrate. The brain drain literature stipulates that low-skill workers adjust their wage requirements on skilled wages, so that relative wages on the one hand and the skilled labor differential between two successive periods, can explain growth, development as well as poverty decrease. Hence, the higher integration of highly skilled labor markets generates some spillover effects on low wages. On the whole, highly skilled emigration can increase unemployment for all types of workers . That last argument is also the one given by our model. Third, the brain drain can induce important occupational shortages which can be strongly detrimental to origin countries if these are concentrated in particularly strategic sectors and professions (such as teachers, engineers, physicians, nurses). If the tasks performed by these professionals strongly affect the productivity of other workers or the accumulation of human capital in the economy, as could be argued for example from an 0-ring perspective (Kremer, 1993), then their departure may have a disproportionately high negative effect on those left behind. Fourth, development stagnation due to growth absence caused by unstable climate and the brain drain as well as rural migrations, making poverty emerge as already noticed, can also lead to famine and diseases. To show that, let poverty reduction function be defined such as the skilled labor differential rate given in equation (25) i.e 


$$
\Delta P R=\frac{\pi_{t}-\pi_{t-1}}{\pi_{t-1}}=-1+\frac{S_{t}^{\bar{d}}}{S_{t-1}^{\bar{d}}}\left(\frac{1-p S_{t}^{\bar{d}}}{1-p S_{t-1}^{\bar{d}}}\right)
$$

Indeed, if $p \rightarrow 0$ while current human capital stock is higher than past human capital stock, then poverty reduction occurrence is high in the long run and the growth rate is $g=\mu S_{t}^{\bar{d}}$, otherwise if $p \rightarrow 1$, then there is no reduction of poverty and growth is low, only equal to $g=\mu$ and skilled workers needed to absorb innovations in the production sector are absent, finally if $0<p<1$, poverty reduction is quite positive and growth is at its average level, $g=\mu \pi_{t}$

Proposition 3: Economic development depends on human capital available in the country, the economic growth rate and poverty reduction such that: if technological change growth rate is lower than the remaining proportion of highly skilled labor i.e $\mu<\pi_{t}$ because $\mathrm{p} \rightarrow 1$, then the brain drain decreases economic growth and increases poverty since $\delta<\mu$ which leads to famine and disease increase. If $\mu>\pi_{t}$ because $\mathrm{p} \rightarrow 0$, then the brain drain doesn't decreases economic growth and poverty where $0<\delta<\mu$. If $\mu \approx \pi_{t}$ because $0<\mathrm{p}<1$, the brain drain doesn't affect economic growth and poverty reduction too much where $\mu \geq \delta$.

According to proposition 3, development depends on human capital accumulation which creates externalities with low skilled labor in production. Indeed, since human capital drives innovations and research development which are engines of growth, development is enhanced. Therefore, since the unskilled labors are kept constant in the space, there is no dualism and economic growth as well as poverty reduction are not altered.

To investigate the brain drain impact on human capital accumulation in this model, we have used the fact that a country's pre-migration stock of human capital can be endogenous to the prospect of migration, an idea relatively old given by Bhagwati and Hamada (1974) or McCulloch and Yellen (1977) who recognized that migration prospects increase the expected wage for highly skilled workers and thus stimulate human capital investments. However, in these papers migration was a self-selection process where all would-be migrants at the time the education decision. We extended that idea since, political climate in the country is not good and make agents emigrate in several ways at any time period. The recent theoretical literature which has explored the possibility for high-skill migration to create more human capital exante than is lost ex-post are the works of Mountford $(1995,1997)$, which develop probabilistic migration models with either homogenous (Stark et al., 1998, Vidal, 1998) or heterogenous (Mountford, 1997, Stark et al., 1997, Beine et al., 2001) agents where migration prospects raise the expected return to human capital and can therefore induce more people to invest in education at home. A closely-related, yet differently motivated theoretical argument is that migration enhances the option value of education in a context of volatile domestic returns to human capital. The argument, put forward by Katz and Rapoport (2005) and based on the proposition that since migration allows for escaping bad domestic returns realizations, the option value of education is increased when the volatility of the underlying asset rises. All else equal, this will drive more people to invest in education (there is a brain gain) and the expected net effect on human capital formation is positive. Since high income volatility is another feature of developing countries, the argument applies first and foremost to these countries. However, the same argument can be extended to rich countries, be it through introducing heterogeneous human capital (general and specific, as in Poutvaara (2008)), or asymmetric sectoral shocks. On the whole, if ex-ante more people opt for education while ex-post some of them will leave, under certain conditions it is possible for the incentive or .brain effect. According to the more 
recent brain drain models, education at home is enough for migration towards richer countries to be effective (McKenzie Rapoport (2007) and Docquier Marfouk (2006) data set on emigration rates by education levels).

Proposition 4: When political climate parameter, $\lambda$ is stable, the economy converges to a development sustainability path on which dualism and brain drain cease through time, described by an inverted U-shape curve.

If we join all the situations presented on the tables 1 through 4, development is highlights by an inverted U-shape curve which means that it is sustainable. (see figure 5)

\section{CONCLUSION}

This model has reviewed both the brain drain literature and the earliest work in development economics in order to study the impact of political uncertainty on the growth process in poor countries. We found that development establishment is hard because it is also highly linked to political uncertainty event or security problems. Finally, the model results follows Hirschman concept of development like a "virtuous circle driven by external economies where modernization breeds modernization. Some countries, according to this view, remain underdeveloped because they have failed to get this virtuous circle going, and thus remain stuck in a low level trap". Such a view implies a powerful case for government activism as a way of breaking out of this trap. Finally, the government is the main actor of development occurrence. The world intervention in favor of poorest countries development leave political stability outside of the debates conducted, the key of development is inside not aid or adjustment policies, but more in the head of the country direction. Consequently, the analysis has highlighted in how far political non stability may retard the development process. In how far political climate uncertainty in poor countries can be compared to the European war experience through which the cease of retard in development became effective with the end of the wars and had helped Western countries being strongly developed nowadays. 


\section{Figure 5: summary of the study}

\section{Civil war zone, full under development}

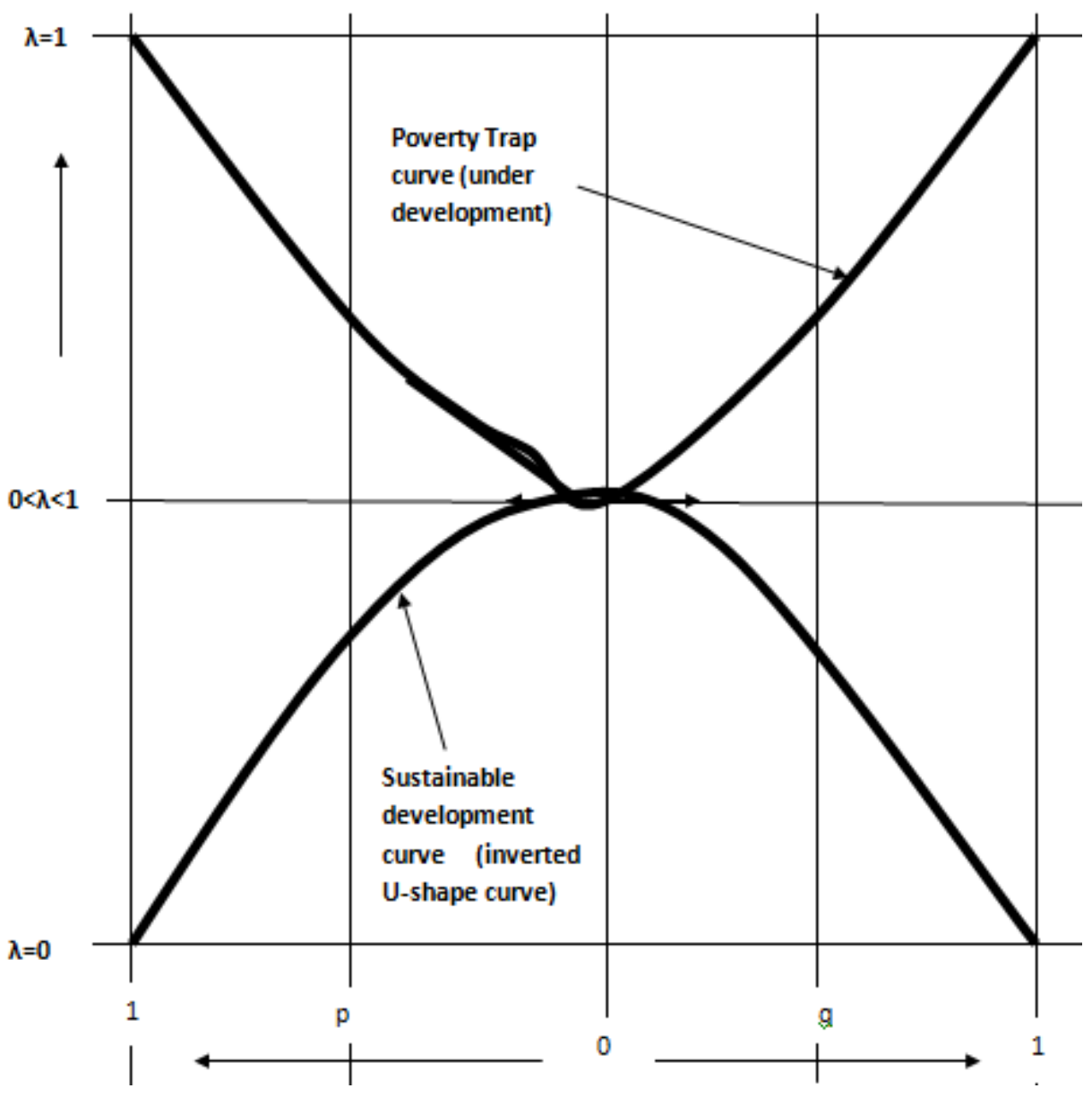

\section{References}

Azariadis, C. and A. Drazen, 1990, Threshold externalities in economic development, Quarterly Journal of Economics, 501-526.

Barro, R.J., 1990, “Government Spending in a Single Model of Endogenous Growth,” Journal of Political Economy, 98(5), 103-125.

Becker, G. (1964), Human Capital, Columbia University Press.

Beine, M., F. Docquier and H. Rapoport (2001): Brain drain and economic growth: theory and evidence, Journal of Development Economics, 64, 1: 275-89.

Berry, A.R. and R. Soligo, 1969, Some welfare aspects of international migration, Journal of Political Economy, 77, 5: 778-94.

Bhagwati, J. (2009): Overview of issues, Chapter 1 in J. Bhagwati and G. Hanson, eds.: Skilled immigration: problems, prospects and policies, Oxford University Press, pp. 3-11.

Bhagwati, J.N. and K. Hamada, 1974, The brain drain, international integration of markets for professionals and unemployment, Journal of Development Economics, 1, 1: 19-42.

Chen, H.-J., 2006, International migration and economic growth: a source country perspective, Journal of Population Economics, 19: 725-48.

Docquier, F., and H. Rapoport (forthcoming), "Globalization, Brain-Drain and

Development," forthcoming work in The Journal of Economic Literature.

Docquier, F., and D. Croix (2012), “Do Brain Drain and Poverty Result from

Coordination Failure?" The Journal of Economic Growth, 17(1), 1-26. 
Eicher, T., 1996, “Interaction between Endogenous Human Capital and Technological Change," Review of Economic Studies, 63, 127-14

Fan, Y.K., 1979, “Emigration and Growth: A Model for Small Developing Countries,” The Journal of Economic Development, 4(2), 141-154.4.

Grubel, H. and A. Scott (1966): The international flow of human capital, American Economic Review, 56: 268-74.

Haque, N. U and S. Kim, 1995, Human capital fight: impact of migration on income and growth, IMF Staff Papers, 42, 3: 577-607.

Hirschman, A., 1958, The Strategy of Economic Development. New Haven, Conn.: Yale University press.

Kanbur, R. and H. Rapoport, 2005, Migration selectivity and the evolution of spatial inequality, Journal of Economic Geography, 5, 1: 43-57.

Kremer, M., 1993, The O-ring theory of economic development, Quarterly Journal of Economics, 108, 3: 551-75.

Krugman, P., 1994, "The Fall and Rise of Development Economics," in Lloyd Rodwin, eds., Rethinking the Development Experience, Brookings Institution Press.

Lewis, W.A., 1954. Economic Development with Unlimited Supplies of Labor The Manchester School. May.

Loubaki, D., 2012, On the Mechanics of the Brain Drain Reduction in Poorest Developing Countries, Journal of Economic Development, Volume 37, Number 3, September 2012, p.75-105

Lucas, R.E., 1988, On the Mechanics of Economic Development, Journal of

Monetary Economics, 22(1), 3-42

McCullock, R. and J.T. Yellen, 1977, Factor mobility, regional development and the distribution of income, Journal of Political Economy, 85, 1: 79-96.

McKenzie, D. and H. Rapoport (2007): Network effects and the dynamics of migration and inequality: theory and evidence from Mexico, Journal of Development Economics, 84,1: 1-27.

Myrdal, G., 1957, Economic Theory and Under-developed Regions. London: Duckworth.

Miyagiwa, K., 1991, Scale economies in education and the brain drain problem, International Economic Review, 32, 3: 743-59.

Mountford, A. and H. Rapoport, 2010, The Brain Drain and the World Distribution of Income, Journal of Development Economics, forthcoming.

Poutvaara, P., 2008, Public education in an integrated Europe: studying to migrate and teaching to stay?, Scandinavian Journal of Economics, 110, 3: 591-608.

Romer, P.M. , 1986, Increasing returns and long-run growth, Journal of Political Economy, 94, 5: 1002-37.

Rosenstein-Rodan, P.N. (1943), "Problems of Industrialization of Eastern and South Eastern Europe," Economic Journal, 53(210-211), 202-211.

Rostow, W.W. (1960), The Stages of Economic Growth, Cambridge University Press.

Solow, R.M., 1956, A Contribution to the Theory of Economic Growth, Quarterly Journal of Economics, 70(1), 6594.

\section{Proof of proposition 1}

\section{APPENDIX}

The steady state in human capital accumulation is defined by $S_{t}^{\bar{d}}=S_{t-1}^{\bar{d}}=S^{\bar{d}}$ we know that $S_{t}^{\bar{d}}=\frac{\beta / 1+\beta}{1+\left[\left(\frac{1+\beta+\lambda}{1+\beta}\right)\left(\frac{1+\mu S_{t-1}^{\bar{d}}}{\delta}\right)\right]}$ 
Indeed, we have: $S_{t}^{\bar{d}}\left[1+\left[\left(\frac{1+\beta+\lambda}{1+\beta}\right)\left(\frac{1+\mu S_{t-1}^{\bar{d}}}{\delta}\right)\right]\right]=\beta / 1+\beta$

Setting $S_{t}^{\bar{d}}=S_{t-1}^{\bar{d}}=S^{\bar{d}}=\mathrm{x}$, we can write

$A x^{2}+B x-C=0$

Where

$A=\left[\left(\frac{1+\beta+\lambda}{1+\beta}\right)\left(\frac{\mu}{\delta}\right)\right], \quad B=\left[1+\left(\frac{1+\beta+\lambda}{1+\beta}\right)\left(\frac{1}{\delta}\right)\right], \quad C=\beta / 1+\beta$

$\Delta=B^{2}+4 A C>0 \quad$ there is only one positive solution which can be written such that $x=\frac{-B+\left(B^{2}+4 A C\right)^{1 / 2}}{2 A}=\frac{1}{2 A} B\left[-1+\left(1+\frac{4 A C}{B^{2}}\right)^{1 / 2}\right]=\frac{B}{2 A}\left[-1+1+1 / 2\left(\frac{4 A C}{B^{2}}\right)\right]$

Because

$\left(1+\frac{4 A C}{B^{2}}\right)^{1 / 2} \approx 1+\frac{1}{2}\left(\frac{4 A C}{B^{2}}\right)$

Indeed

$x=\frac{C}{B}=S^{*}$ i.e

$$
S^{*}=\frac{\beta / 1+\beta}{1+\frac{1}{\delta}\left(\frac{1+\beta+\lambda}{1+\beta}\right)}
$$

Thus, the growth rate is given by the following expression i.e

$$
g=\frac{\mu \beta / 1+\beta}{1+\frac{1}{\delta}\left(\frac{1+\beta+\lambda}{1+\beta}\right)}
$$

